\title{
Bidenichthys okamotoi, a New Species of the Bythitidae (Ophidiiformes, Teleostei) from the Koko Seamount, Central North Pacific ${ }^{\dagger}$
}

\author{
Peter R. Møller ${ }^{1,2, *}$, Werner W. Schwarzhans ${ }^{1, \ddagger}$, Henrik Lauridsen ${ }^{3} \mathbb{D}$ and Jørgen G. Nielsen ${ }^{1}$ \\ 1 Natural History Museum of Denmark, University of Copenhagen, Universitetsparken 15, \\ DK-2100 Copenhagen, Denmark; wwschwarz@aol.com (W.W.S.); jgnielsen@snm.ku.dk (J.G.N.) \\ 2 Norwegian College of Fishery Science, UiT The Arctic University of Norway, 9037 Tromsø, Norway \\ 3 Department of Clinical Medicine, Aarhus University, Aarhus N, DK-8200 Aarhus, Denmark; \\ henrik@clin.au.dk \\ * Correspondence: pdrmoller@snm.ku.dk; Tel.: +45-20116643 \\ † Publications: urn:lsid:zoobank.org:pub:D5F2707A-CCB3-4FA3-B717-8A1AE8F30E4A; \\ urn:lsid:zoobank.org:act:2ED986A9-5283-414E-9E4E-DAF2F1CC7A3A \\ $\ddagger$ Private address: Ahrensburger Weg 103, 22359 Hamburg, Germany.
}

Citation: Møller, P.R.; Schwarzhans, W.W.; Lauridsen, H.; Nielsen, J.G. Bidenichthys okamotoi, a New Species of the Bythitidae (Ophidiiformes, Teleostei) from the Koko Seamount, Central North Pacific. J. Mar. Sci. Eng 2021, 9, 1399. https://doi.org/ 10.3390/jmse9121399

Academic Editor: Alexei M. Orlov

Received: 2 November 2021

Accepted: 2 December 2021

Published: 8 December 2021

Publisher's Note: MDPI stays neutral with regard to jurisdictional claims in published maps and institutional affiliations.

Copyright: (c) 2021 by the authors. Licensee MDPI, Basel, Switzerland. This article is an open access article distributed under the terms and conditions of the Creative Commons Attribution (CC BY) license (https:/ / creativecommons.org/licenses/by/ $4.0 /)$.
Abstract: Two specimens from the Koko Seamount (Koko Guyot), in the Hawaiian-Emperor seamount chain, Central North Pacific, caught in 2009 and 2010 are here described as a new species, Bidenichthys okamotoi. The taxonomy of the species in the genera Bidenichthys Barnard, 1934, and Fiordichthys Paulin, 1995, has been confusing due to the lost type of B. consorbrinus (Hutton, 1876) and the rarity of some of the species. Following the synonymization of Fiordichthys Paulin, 1995, with Bidenichthys by Møller and Nielsen 2015 and of Bidenichthys beeblebroxi Paulin, 1995, with Bidenichthys consobrinus Hutton, 1876, the genus Bidenichthys now comprises five species: B. capensis, B. consobrinus, B. okamotoi, B. paxtoni and B. slartibartfasti. Bidenichthys okamotoi differs from its congeners in, e.g., the fewer precaudal vertebrae (12 vs. 13), more palatine teeth rows (4-6 vs. $2-3)$, shorter pelvic fins (12.1-13.4\% vs. $14.4-21.0 \%$ SL), max size (187 vs. $147 \mathrm{~mm} \mathrm{SL}$ ) and the shape of the sulcus of the otolith. We here present an updated diagnosis of the genus. A computed tomography (CT) scan of the holotype of B. okamotoi provides for additional anatomical details. The disjunctive occurrence of Bidenichthys okamotoi on the Emperor Seamount chain about $7500 \mathrm{~km}$ from the nearest congeneric taxon in New Zealand is discussed. The fossil otolith-based record of the genus Bidenichthys and its systematic implications is briefly discussed.

Keywords: viviparous brotulas; livebearing brotulas; taxonomy

\section{Introduction}

The genus Bidenichthys was established by Barnard [1] in 1934 based on specimens collected in 1929 from St. James, False Bay and Still Bay, in Riversdale, South Africa. The genus was named after one of the collectors, Mr. C. L. Biden. Barnard noticed that his new species B. capensis belonged to a "small group of Brotulids which have the dorsal and anal fins free from the caudal ... ". Today, Bidenichthys is placed in the family Bythitidae and is characterized by a male copulatory organ with penis and pseudoclaspers more or less fused, differing from the family Dinematichthyidae with free penis, and pseudoclaspers [2] Barnard [1] defined the genus and species partly on the very long pectoral fin peduncle and mentioned that the nearest species was Dinematichthys consorbrinus [3] from New Zealand, based on the figure in Hector [4]. The latter species was later also assigned to Bidenichthys but was also confused with B. paxtoni [5] by Paulin [6,7]. Following the synonymization of Fiordichthys [6] with Bidenichthys [7], and of B. beeblebroxi [6] with B. consobrinus [3], the genus Bidenichthys now comprises four extant species: B. capensis, B. consobrinus, B. paxtoni and B. slartibartfasti. In 2009 and 2010, two specimens of a putative fifth species were caught 
in 315-387 m depth at the Koko Seamount by Japanese researchers from the Seikai National Fisheries Research Institute. The species is here described a new species Bidenichthys okamotoi n. sp.

\section{Materials and Methods}

Measurements and counts were made according to Nielsen et al. [8]. Standard length (SL) and head length (HL) are used throughout. Head pore nomenclature follows Møller et al. [9]. In the descriptions, holotype data are given first, followed by the paratype in parentheses. Institutional abbreviations follow Sabaj [10]. + means that this is a fossil species. Micro-CT imaging was performed on the holotype of Bidenichthys okamotoi using a Scanco Medical XtremeCT system (Scanco, Brüttisellen, Switzerland) using the following parameters: X-ray tube voltage $=59.4 \mathrm{kVp}, \mathrm{X}$-ray tube current $=90 \mu \mathrm{A}$, integration time $=100 \mathrm{~ms}$, field-of-view $=66.3 \times 69.6 \times 144.3 \mathrm{~mm}^{3}$, spatial resolution $=0.082 \mathrm{~mm}$ isotropic, acquisition time $=1 \mathrm{~h}$. To cover the entire specimen, two subsequent scans were performed of the anterior and posterior portion of the specimen, and these were concatenated using ImageJ (1.52 n). Osirix DICOM viewer was used for volume reconstruction of the mineralized components of the skeleton. The Micro-CT data of the holotype (ZMUC P2397717) are available on MorphoSource: https:/ / www.morphosource.org/ (accessed on 3 December 2021) media\# 000399631, 000399635. Comparative materials are listed in Appendix A.

\section{Study Area}

The Koko Seamount is located near the southern end of the Emperor Seamount chain that was formed by volcanic activity above the Hawaiian mantel plum during the Late Cretaceous and Paleogene from 75.8 to $39.9 \mathrm{Ma}$ [11]. This was before the movement of the Pacific Plate switched to a more west-east oriented path of the volcanic track that is still active and gave rise to the Hawaiian Island chain. The Koko Seamount has been drilled three times during the DSDP and ODP campaigns (sites 308 and 309 in 1975, and 1206 in 2002 [12]) and was found to have formed at about 50.4 Ma during the early Eocene (Ypresian) [13]. The Koko Island submerged at about 36.5 Ma (late Eocene, Priabonian). Corals grew on Koko from about 50 to $27 \mathrm{Ma}$ and the shallow water coral reef probably deceased at about $33 \mathrm{Ma}$, replaced by a deep water coralgal rudstones until the early Miocene (20-16 Ma) [12]. Since then, the Koko Seamount became a large, flat-topped drowned guyot and has continued to subside to its current depth, with the top at about $260 \mathrm{~m}$ depth [14].

\section{Results}

Systematic Part

Genus Bidenichthys Barnard [1]

Type species: Bidenichthys capensis Barnard [1]

Diagnosis (updated from Nielsen et al. [8]):

Head and body robust, depth at origin of anal fin 15.2-20.8\% SL; body covered with scales. Eye diameter less than snout length; maxilla slender, strongly expanded posteriorly and with a deep and broad ventral notch; anal fin-origin far posterior to midpoint of body. Dorsal fin rays 66-87, caudal fin rays 14 (free from dorsal and anal fins), anal fin rays 36-50, pectoral fin rays 20-30, pelvic fin rays 1 , vertebrae $12-16+27-34=40-47$, branchiostegal rays $7-8$, total gill rakers $13-27$. 
Species: Extant: Bidenichthys capensis Barnard [1], South Africa from East London to Cape in rocky tidepools; Bidenichthys consobrinus [3] (syn. Bidenichthys beeblebroxi [6], New Zealand North Island and upper South Island, 1-30 m depth; Bidenichthys okamotoi n. sp., Koko Seamount, North Pacific, 315-387 m depth; Bidenichthys paxtoni [5], off SW Australia and northern New Zealand, 30-300 m depth; Bidenichthys slartibartfasti [6], New Zealand, Fjordland, South Island, 83-337 m depth. Fossil otolith-based: Bidenichthys struthersi [15], New Zealand, South Island, early Miocene (Altonian, 18.5-16 Ma).

Bidenichthys okamotoi n. sp.

Figures 1-4

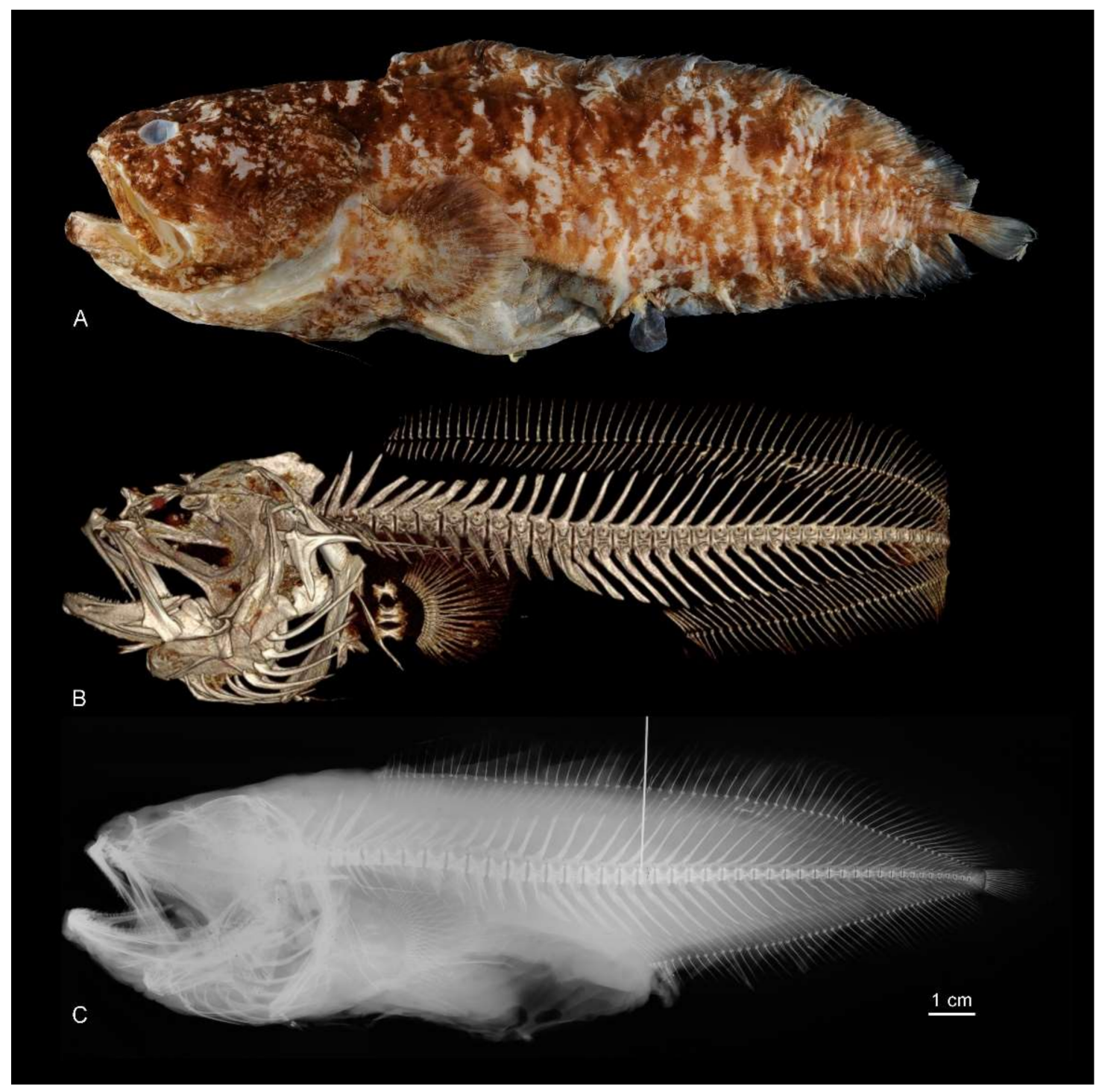

Figure 1. Bidenichthys okamotoi n. sp., holotype ZMUC P239717, (A), photograph; (B), CT scan; (C), radiograph. 


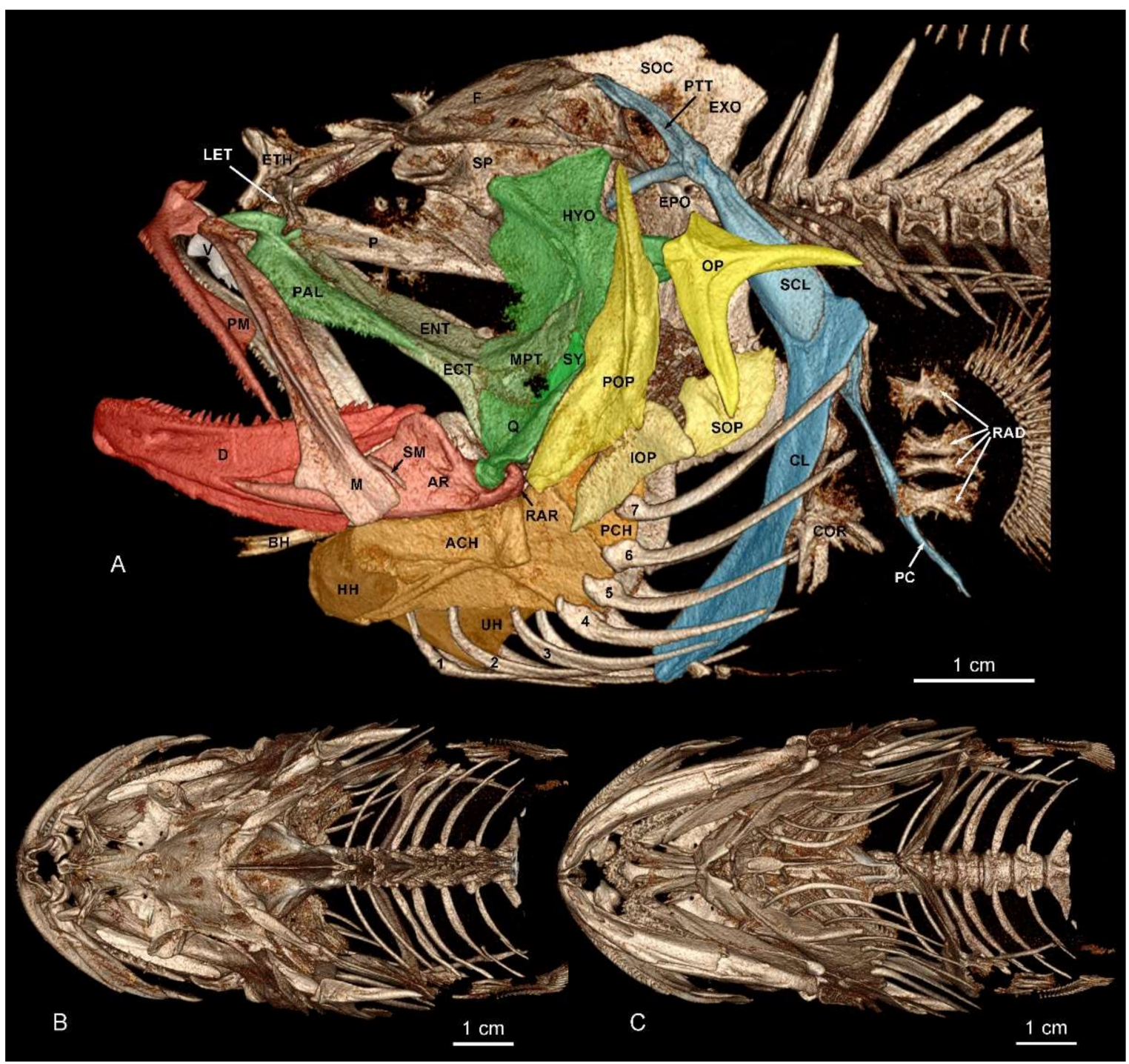

Figure 2. Bidenichthys okamotoi n. sp. CT scans of the skull of the holotype, ZMUC P2397717, (A), lateral view, (B), dorsal view, (C), ventral view; (A) is color-coded with acronyms for individual bones as follows: Red = oral jaw, $\mathrm{AR}=$ articular, $\mathrm{D}=$ dentary, $\mathrm{M}=$ maxilla, $\mathrm{PM}=$ premaxilla, $\mathrm{RAR}=$ retroarticular, $\mathrm{SM}=$ supramaxilla; Green = suspensorium, ECT = ectopterygoid, ENT = entopterygoid, $\mathrm{HYO}=$ hyomandibular, $\mathrm{MPT}=$ mesapterygoid, $\mathrm{PAL}=$ palatine, $\mathrm{Q}=$ quadrate, $\mathrm{SY}=$ symplectric; Yellow = opercular series, $\mathrm{IOP}=$ interopercle, $\mathrm{OP}=$ opercle, $\mathrm{POP}=$ preopercle, $\mathrm{SOP}=$ subopercle; Brown = Hyoid bar, $\mathrm{ACH}=$ anterior ceratohyal, $\mathrm{BH}=$ basihyal, $\mathrm{HH}=$ hypohyal, $\mathrm{PCH}=$ posterior ceratohyal, $\mathrm{UH}=$ urohyal, branchiostegal rays (uncolored) numbered from 1 to 7 ; Blue = pectoral girdle, $\mathrm{CL}=\mathrm{cleithrum}, \mathrm{COR}$ (uncolored) $=$ coracoid, $\mathrm{PC}=$ postcleithrum, PTT = posttemporal, RAD (uncolored) = radials, SCL = supracleithrum; White or uncolored = neurocranium, EPO = epioccipital, ET = ethmoid, EXO = exoccipital, F = frontal, LET = lateral ethmoid, $\mathrm{P}=$ parasphenoid, $\mathrm{SOC}=$ supraoccipital, $\mathrm{SP}=$ sphenotic, $\mathrm{V}=$ vomer. 

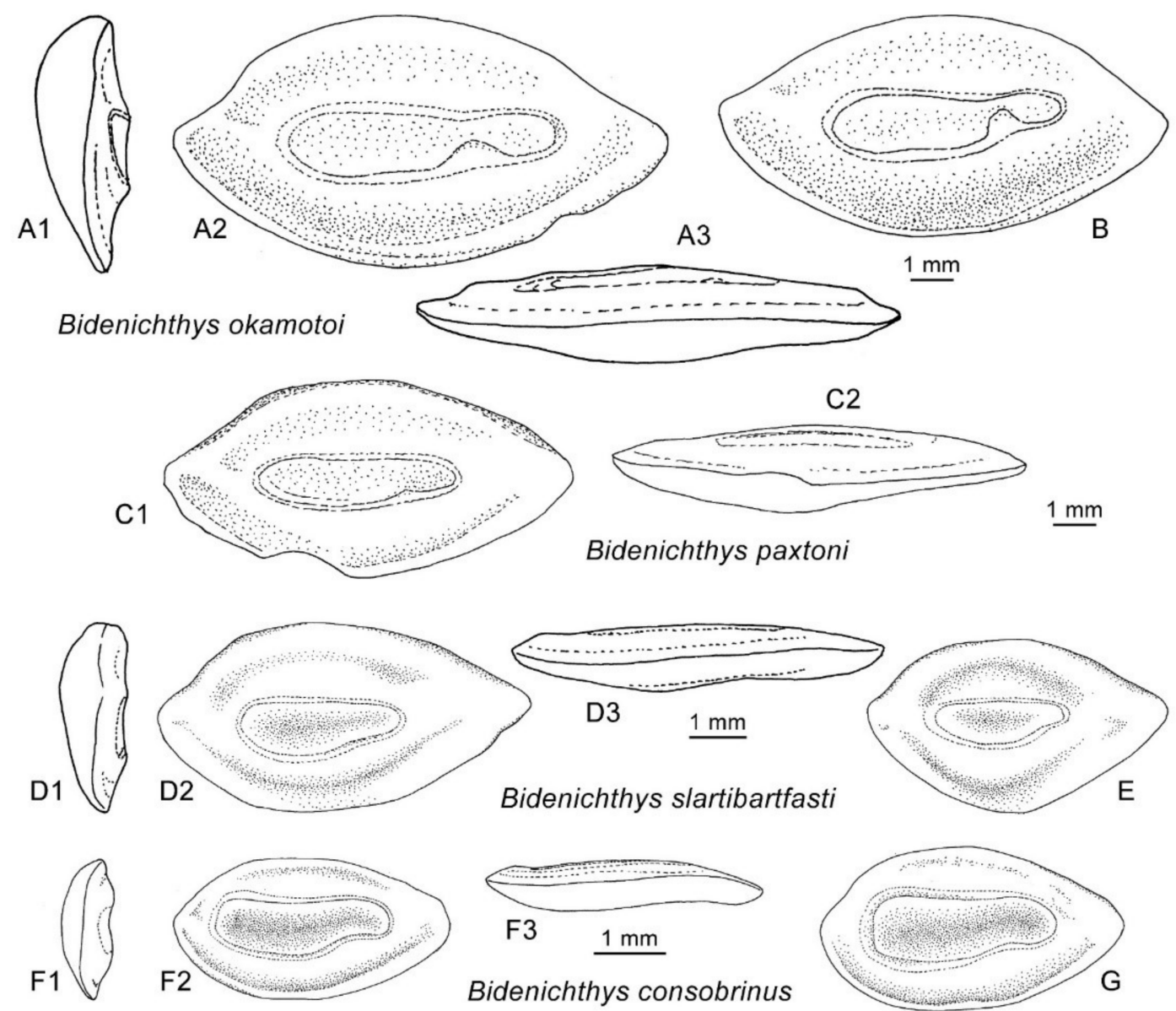

Bidenichthys consobrinus
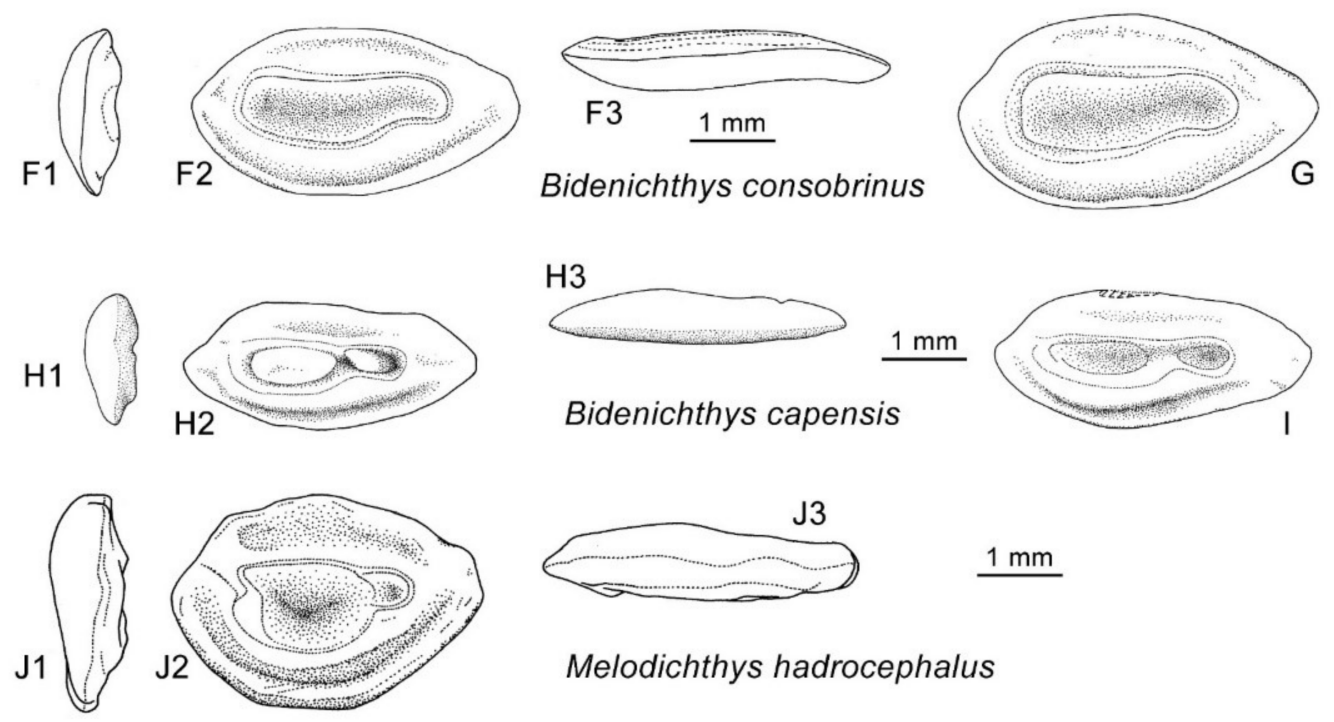

Figure 3. Otoliths inner faces and selected anterior and ventral views (H3 + J3 = dorsal views); A,B, Bidenichthys okamotoi $\mathrm{n}$. sp. (A, holotype, ZMUC P2397717, B, paratype, ZMUC P2397390); C, Bidenichthys paxtoni [5], NMNZ 18430; D,E, Bidenichthys slartibartfasti [6], NMNZ 35097; F,G, Bidenichthys consobrinus [3], ZMUC P77800-03; H,I, Bidenichthys capensis [1], ZMUC P77470; J, Melodichthys hadrocephalus [5], MNHN 1980-392. 


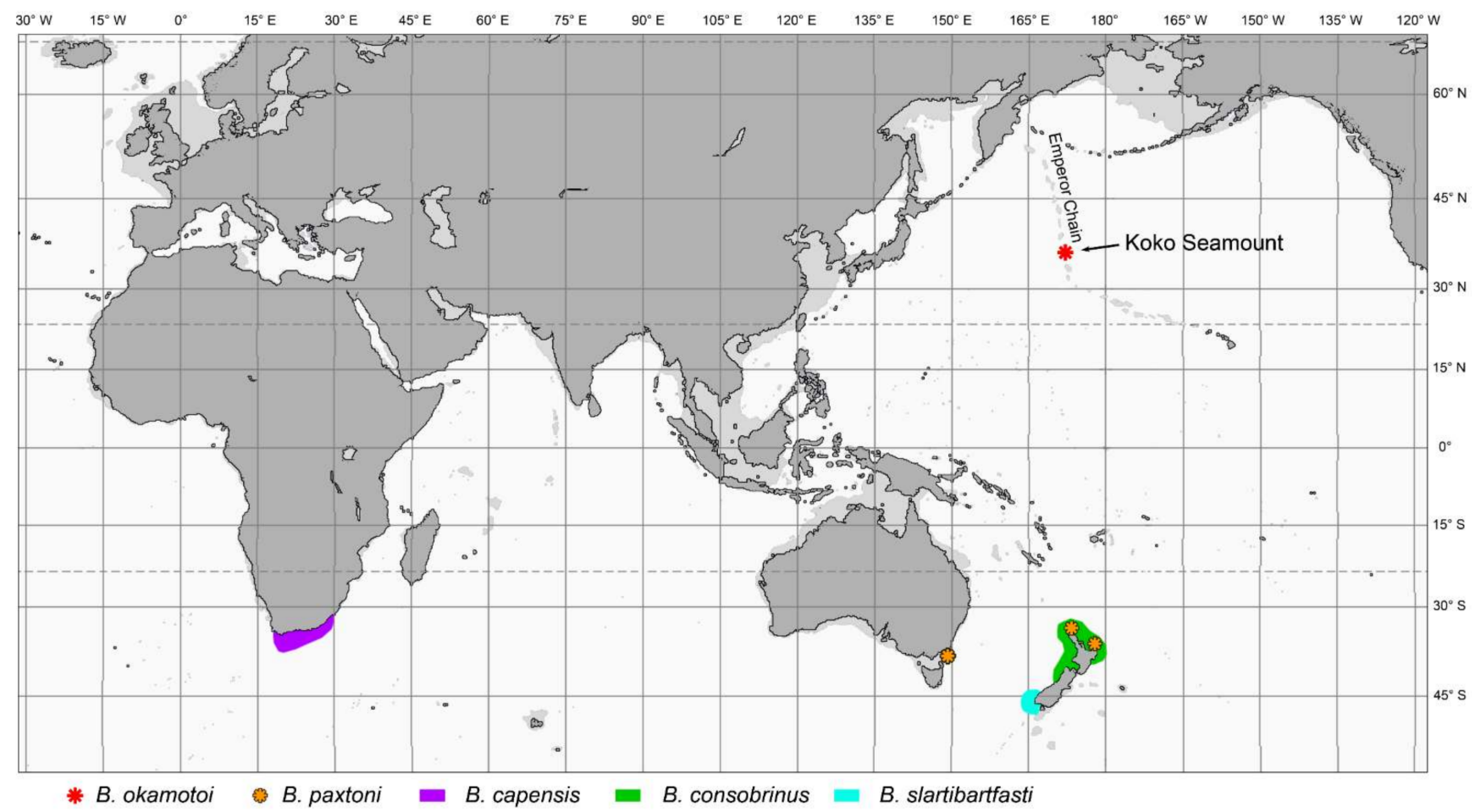

Figure 4. Geographic distributions of extant Bidenichthys species.

Holotype: ZMUC P2397717, Figures 1B,C, 2 and 3A, $187 \mathrm{~mm}$ SL male, 35.36' N, $171.21^{\prime}$ E, 315 m, 23 March 2010, collected by Dr. Makoto Okamoto, AFFRC, Seikai National Fisheries Research Institute.

Paratype: ZMUC P2397390, Figures 1A and 3B, $169 \mathrm{~mm}$ SL female, 35.19' N, 171.48' E, 387 m, 13 October 2009, collected by Dr. Makoto Okamoto, AFFRC, Seikai National Fisheries Research Institute.

Diagnosis:

Bidenichthys okamotoi is distinguished from other members of the genus by the following combination of characters: dorsal fin rays 69 (70); anal fin rays 48 (47); pectoral fin rays 21 , caudal fin rays 14 ; total vertebrae $12+33=45(12+34=46)$; palatine teeth rows $6(4)$; rakers on anterior gill arch 27 (22) (long gill-rakers 17 (13); diameter of pigmented eyes $4.3(4.1) \% \mathrm{SL}$; length of pelvic fin $12.1(13.4) \% \mathrm{SL}$; upper part of head scaled, scale rows above anal fin origin 68 (67); color light brown, with irregular white blotches on head, body and fins; sulcus of otolith with ventrally deeply indented colliculum at junction of ostium and cauda.

Description of holotype (paratype values in brackets):

Additional meristic and morphometric characters are given in Table 1. Body robust, high and moderately elongate and compressed posteriorly. Head profile mildly rounded (Figure 1). Lower jaw slightly protruding. Anterior nostril tube-shaped, placed low on snout near upper lip; posterior nostril a simple hole, close to the anterior margin of eye. Anterior gill arch with 17 (13) elongate rakers and 10 (9) short rakers arranged in the following configuration: lower branch with 5 short rakers followed by 15 (11) long rakers, upper branch with two long rakers followed by 5 (4) short rakers. Pseudobranchial filaments 2. Scales on body small, non-imbricate, oval, 68 (67) horizontal rows above anal fin origin; diameter up to ca. $1.4 \mathrm{~mm}$ horizontally at mid-body; proximal half of vertical fins and pectoral fin covered with small scales, distal half naked. Predorsal area and top of head and snout scaled. Origin of dorsal fin above base of pectoral fins. Pelvic fin with a single ray reaching to about a vertical trough pectoral peduncle. Pectoral fin on lower half of body, peduncle short and high. Caudal fin free not fused with dorsal and anal fins. 
Head sensory pores: Supraorbital pore 1; infraorbital pores 3 (3 anteriorly and 0 posteriorly); mandibular pores 2 ( 2 anterior and 0 posterior); preopercular pores 1 (1 lower and 0 upper). Lateral line with ca. 17 dorsal neuromasts anteriorly and ca. 30 medio-lateral neuromasts posteriorly.

Dentition: Premaxilla with seven (four) rows of small granular teeth, slightly larger in outer row. Vomer with four teeth rows. Palatines with six (four) teeth rows of small, pointed teeth. Dentary with four (three) outer rows of granular teeth and an inner row of longer, pointed teeth (Figure 2A).

First neural spine about $2 / 3$ the length of second spine; spine 2-3 slightly longer and more pointed than spines 4-13; spines 4-11 slightly depressed. Parapophyses present from vertebra 7-13, increasing in length. Pleural and epipleural ribs on vertebrae 1-12. Last precaudal vertebra without ribs. Male copulatory organ of the paratype completely integrated in the fleshy genital hood.

A high resolution CT scan of the holotype (Figures 1B and 2) allows for a first description of skull bones in the genus and bythitids in general. Some bones and parts are not resolved because of their cartilaginous nature, such as the infraorbital series, nasal, part of the coracoid and scapula. Therefore, these are excluded from the description. Small parts of the anterior margin of the hyomandibula and small sections within the metapterygoid and symplectic are also cartilaginous and are not visualized on the CT scan.

Premaxilla with short, broad articular and ascending processes and strong, triangular postmaxillary process, bearing many teeth. Maxilla slender, strongly expanded posteriorly as typical for many ophidiiforms, but with deep and broad ventral notch otherwise known from only few dinematichthyids and bythitids; supramaxilla slender. Dentary massive with many strong conical teeth. Anguloarticular with broad, short articular condyle; retroarticular only partly exposed.

Suspensorium: Palatine broad, massive, with prong located at upper anterior position followed by narrow, nearly vertically oriented thin process, bearing many teeth. The outline of entopterygoid, ectopterygoid, quadrate, metapterygoid and symplectric mostly well discernible. Hyomandibula large, with broad and long opercular process, its stem well expressed and bent forward in its upper section; upper shelf almost triangular in shape with deep notch towards opercular process; anterior shelf broad; no hyomandibular foramen discernible.

Hyoid bar: Anterior ceratohyal massive, broad, with branchiostegal rays 1 through 5 articulating along its course; branchiostegal rays 6 and 7 articulating with posterior ceratohyal. Branchiostegal rays 1-3 narrow based, 4-7 with broad base. Basihyal and hypohyal discernible, but latter without apparent distinction of upper and lower hypohyals; urohyal partly visible.

Opercular series: Preopercle narrow, long, shelf-like; opercle V-shaped with long upper spine and narrow lower shelf; subopercle and interopercle relatively small.

Neurocranium: Exposed or partly exposed and discernible bones are vomer, ethmoid, lateral ethmoid, frontal, sphenotic, parasphenoid, supraoccipital, exoccipital and epioccipital. Supraoccipital crest composed about same extent by supraoccipital and a much expanded exoccipital, a trait that Howes [16] and Carnevale and Johnson [17] considered a synapomorphy for the Ophidiiformes.

Pectoral girdle: Cleithrum, supracleithrum, postcleithrum and posttemporal are all well discernible while coracoid and scapula are only partly discernible due to their cartilaginous nature. Cleithrum long, blade-like with expanded lower part and broad articulation with coracoid and scapula along its central and upper region. Postcleithrum long, slender, slightly widened at upper part at articulation with upper part of cleithrum. All four pectoral-fin radials clearly discernable.

Otoliths $(n=2)$. Relatively large otoliths, up to $11.8 \mathrm{~mm}$ in length. Otolith shape fusiform with gently and regularly curved dorsal and ventral rims and equally pointed anterior and posterior tips at level. Otolith length: otolith height $=1.95-2.0$; otolith height: otolith thickness about 2.5 . Inner face slightly convex with centrally positioned, slightly 
upward tilted, shallow sulcus. Otolith length: sulcus length $=1.85-1.95$. Sulcus terminating far from anterior and posterior otolith tips at about same distance. Colliculi well defined; ostial and caudal colliculum fused only dorsally and separated along ventral stretch by deep notch. Ostium distinctly longer and slightly wider than cauda. Ostium length: cauda length (measured along free colliculi margins) $=2.2-2.7$. Dorsal depression indistinct; ventral furrow very wide, sharp ventral and gradual dorsal margins. Otolith rims and outer face smooth.

Color light brown, with irregular white blotches on head, body and fins. Paratype (Figure 1A) in better condition than Holotype. The latter seems to have lost some of the coloration either during capture or preservation.

Etymology

The species is named after the collector of the two types, Dr. Makoto Okamoto, AFFRC, Seikai National Fisheries Research Institute, in honor of his many contributions to Pacific ichthyology.

Remarks

Bidenichthys okamotoi differs from its congeners in, e.g., the fewer precaudal vertebrae (12 vs. 13), more palatine teeth rows (4-6 vs. $2-3)$, shorter pelvic fins $(12.1-13.4 \%$ vs. $14.4-21.0 \% \mathrm{SL}$ ), max size (187 vs. $147 \mathrm{~mm} \mathrm{SL}$ ) and the shape of the sulcus of the otolith. It is difficult to pick the species most similar to B. okamotoi. It resembles B. paxtoni in the non-uniform coloration and otolith shape (see discussion), but shares the exact number of head pores only with B. consobrinus.

Key to species

1a. Pectoral-fin peduncle longer than broad; anal fin rays $36-41 \ldots \ldots \ldots \ldots$. . . capensis

1b. Pectoral-fin peduncle broader than long; anal fin rays $42-50 \ldots \ldots \ldots \ldots \ldots \ldots 2$

2a. Pelvic fins length $12.1-13.4 \%$ SL; palatine teeth rows $4-6 \ldots \ldots \ldots \ldots \ldots$. okamotoi

2b. Pelvic fins length $14.4-21.0 \%$ SL; palatine teeth rows $2-3 \ldots \ldots \ldots \ldots \ldots \ldots$

3a. Posterior mandibular head pores 0 ; long gill rakers $5-8$; dorsal fin rays $78-87 \ldots \ldots \ldots$

B. consobrinus

3b. Posterior mandibular head pores 3; long gill rakers 10-17; dorsal fin rays $68-77 \ldots \ldots 4$

4a. Distance from ventral fin insertion to anal fin origin $42.0-46.9 \%$ SL; supraorbital head

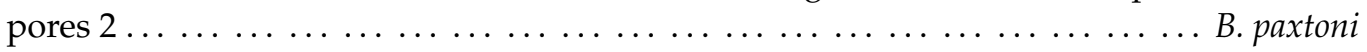

4b. Distance from ventral fin insertion to anal fin origin 34.0-38.6\% SL; supraorbital head

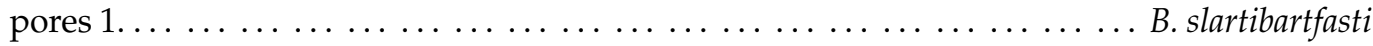


Table 1. Meristic and morphometric characters of Bidenichthys spp.

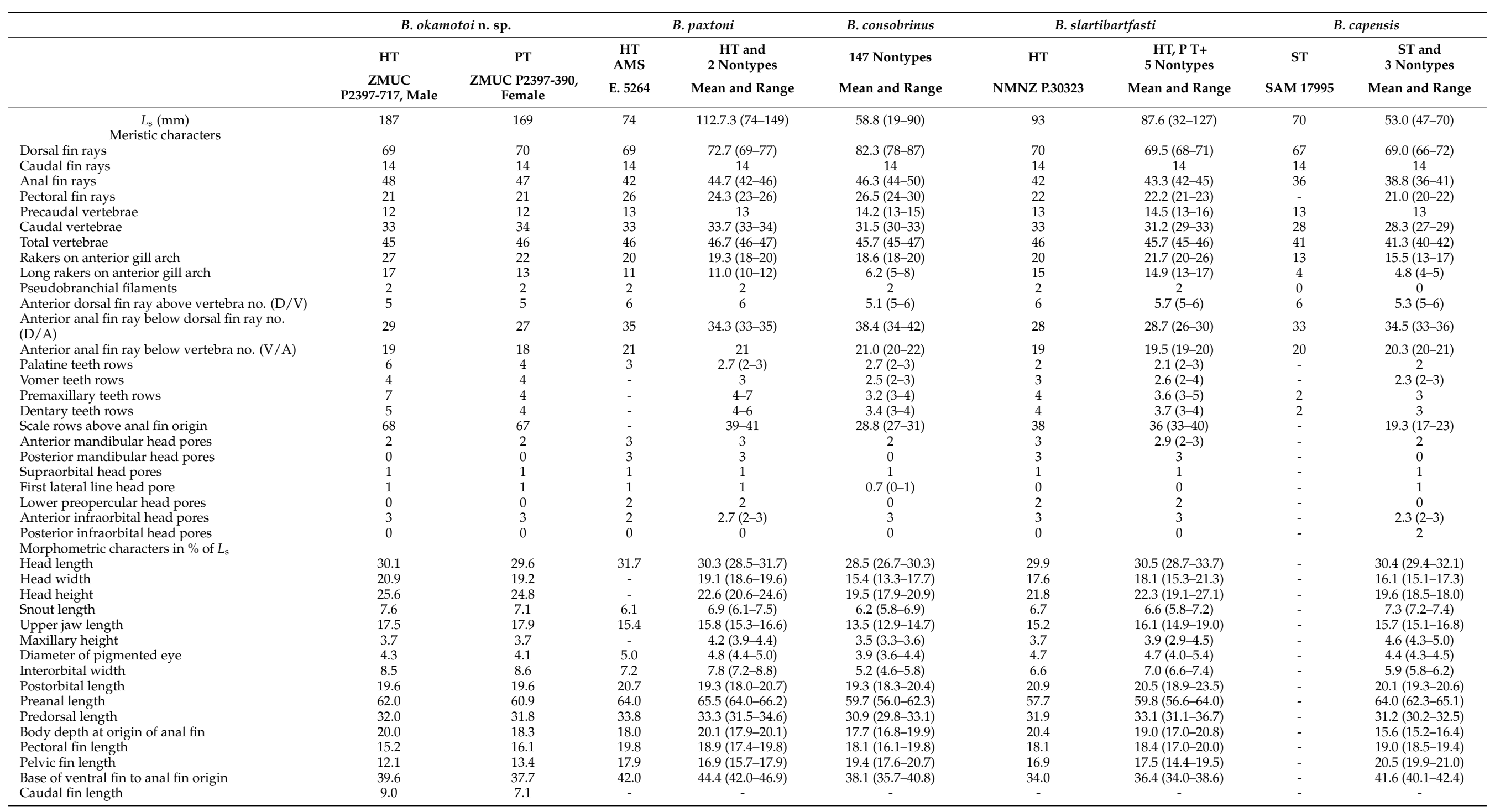




\section{Discussion}

Sagittal otoliths (Figure 3A,B): The otoliths of the five species currently recognized in Bidenichthys show a clear morphological differentiation. Those of B. okamotoi most resemble B. paxtoni (Figure 3C) but differ in the near separation of the ostial and caudal colliculi (vs. completely fused), and the wider sulcus, particularly its ostial part. The otoliths of B. consobrinus (Figure 3F-G) are remarkable for their very wide and large sulcus with completely fused colliculi and thus represent a different morphology than B. okamotoi. The otoliths of B. slartibartfasti (Figure 3D,E), in contrast, differ in their very short and nearly uniform sulcus and the deepened ventral rim. The otoliths of B. capensis (Figure 3H,I) differ from all other extant Bidenichthys species in the completely and widely separated colliculi, which are also somewhat deepened, and the very slender shape. They clearly represent a different phylogenetic lineage that must have been separated from the West-Pacific ones for a lengthy period of time in the geological past. The otolith of the holotype of Melodichthys hadrocephalus [5] is figured for comparison (Figure 3J), and differs from Bidenichthys species in the compressed shape and the unusually widened ostium.

Comment on the fossil record: Fossil bythitids are generally rare and mostly known from otoliths. Most bythitid otoliths show a rather simple sulcus morphology with fused colliculi and very often a simple oval sulcus outline terminating distant from the anterior and posterior otolith tips [18-20]. This has greatly hindered systematic work with them. Few bythitid genera contain otoliths with clearly separated colliculi, which is considered the plesiomorphic character state. Of the recent taxa, only Bidenichthys capensis and Melodichthys hadrocephalus and the fossil record tParadiplacanthopoma [19] and tOtarionichthys Gaemers [21] are considered to represent bythitid otolith-based genera with separated colliculi. A number of Late Cretaceous and Paleogene otolith-based taxa have been tentatively allocated with the genus Bidenichthys primarily because of separated colliculi and some overall similarity with otoliths of the extant $B$. capensis. These include †Bidenichthys? crepidatus [22] from the Late Cretaceous, +Bidenichthys? lapierrei [23] from the Paleocene and Eocene, + Bidenichthys? boscheineni [24] from the late Oligocene, and †Bidenichthys? midwayensis [25] from the Paleocene. All these species may actually represent a yet undefined fossil clade near the base of the Bythitoidei [2]. This leaves +Bidenichthys struthersi Schwarzhans [15] (see [15] for figures) as the only valid fossil otolith record of the genus, which is closest to the extant B. slartibartfasti. + Melodichthys heinzelini [26] from the early Pliocene of western France represents the only valid fossil record of Melodichthys. In addition, there is a record from the late Miocene (Tortonian) of northern Italy described as tOgilbia aff. heinzelini [26] that likely represents an undescribed fossil Bidenichthys.

Among the rare records of articulated skeletons, the Late Cretaceous Pastorius methenyi [17] is the most interesting and has been interpreted as a basal bythitoid exhibiting some similarity to the Brosmophycini (then considered a clade within Bythitidae). The vertebrae $(12+27$ vs. $12+29-33)$ and fin-ray count (C 13 vs. 14 ; D 38 vs. 66-78; A 35 vs. $36-50)$ is lower than in Bidenichthys but in the range that might be expected from a basal bythitoid. The maxilla in Pastorius is broadly extended posteriorly with a sharp ventral expansion, much like many ophidiiforms, but in Bidenichthys okamotoi, the ventral termination of the maxilla shows a distinct notch. Both Pastorius and Bidenichthys show a distinct supramaxilla. Premaxilla and palatine are very slender in Pastorius and the premaxilla does not show the strong triangular postmaxillary extension as evident in Bidenichthys okamotoi.

Geographic significance (Figure 4): Of the five extant species of Bidenichthys, three occur in New Zealand (and one of them also in eastern Australia), one in South Africa and now B. okamotoi on the Koko Seamount in the North-Pacific. The only verified fossil record of Bidenichthys is from the early Miocene of New Zealand of a species belonging to a specific clade in the genus. The distribution in South Africa and New Zealand may reflect refugia of a former much wider distribution and are both typical areas of secondary endemics. Bidenichthys okamotoi on the Koko Seamount is the outlier (and the possible fossil record in the late Miocene of Italy). 
The Emperor Chain is known for deep-water fish endemics, the most notable one being the monotypic Adelosebastes with A. latens [27] bathydemersal at 900-1200 m. Recently, Lucigadus borealis [28] was described as endemic to the Koko Seamount and collected at $409 \mathrm{~m}$ depth. The degree of endemisms on seamounts varies widely, and their composition and origin are subject to continued research (e.g., [29-32]). Wilson and Kaufmann [29] regarded $7 \%$ of the fishes of the Emperor Chain as endemic. With the possible exception of Adelosebastes, most of those appear to represent bathydemersal fishes within clades that otherwise are widely distributed in the North Pacific [28].

This is clearly not the case for Bidenichthys okamotoi. The nearest species of Bidenichthys to B. okamotoi are B. paxtoni and B. consobrinus around northern New Zealand, about $7500 \mathrm{~km}$ to the south. The height of the Koko Seamount and the collecting depth of B. okamotoi in nearly $400 \mathrm{~m}$ is the deepest in the genus, and B. paxtoni in this case caught off New Zealand and eastern Australia between 30 and 275 m, possibly $337 \mathrm{~m}$ [7]. The other extant species occur in relatively shallow water mostly between 1 and $30 \mathrm{~m}$. We assume that the currently observed disjunctive distribution of the genus in South Africa, south-east Australia, New Zealand and the Koko Seamount reflects a relict of a formerly much wider distribution. The putative record from the late Miocene of Italy and the long range of one of the clades in New Zealand to about $25 \mathrm{Ma}$ indicates indeed that its distribution may have been much wider in the past and relatively early in time, i.e., before early Miocene. That also corresponds with a time when reefs were still growing around what was then Koko Island, and geographic and oceanographic connectivity might have been different and more favorable for shallow water fishes to reach the area. In our view, the most likely scenario would be that the ancestors of Bidenichthys okamotoi reached Koko Island at some time before its submergence and subsequently became isolated on what is now the crest of the Koko Seamount.

Author Contributions: Conceptualization, P.R.M., W.W.S. and J.G.N.; methodology, P.R.M., W.W.S. and H.L.; validation, P.R.M. and W.W.S.; formal analysis, P.R.M. and W.W.S.; investigation, P.R.M. and W.W.S.; resources, J.G.N., P.R.M. and H.L.; data curation, P.R.M., W.W.S. and H.L.; writing-original draft preparation, P.R.M. and W.W.S.; writing—review and editing, J.G.N. and H.L.; visualization, W.W.S. and H.L.; project administration, P.R.M. All authors have read and agreed to the published version of the manuscript.

Funding: This research received no external funding.

Institutional Review Board Statement: Not applicable.

Informed Consent Statement: Not applicable.

Data Availability Statement: The Micro-CT data of the holotype (ZMUC P2397717) are available on MorphoSource: https: / /www.morphosource.org/ (accessed on 3 December 2021) media\# 000399631, 000399635.

Acknowledgments: Special thanks to Makoto Okamoto, AFFRC, Seikai National Fisheries Research Institute who collected the specimens of the new species and to Marcus A. Krag, Natural History Museum of Denmark for taking photographs of the Holotype. Thanks to Mark McGrouther, The Australian Museum; Andrew L. Stewart, Carl D. Struthers and Clive Roberts, Museum of New Zealand, Te Papa Tongarewa; and James Maclaine, Natural History Museum, London for loan of comparative specimens.

Conflicts of Interest: The authors declare no conflict of interest.

\section{Appendix A}

Comparative Material

Bidenichthys capensis [1]

AMS I.377290-001, 47 and $47 \mathrm{~mm}$ SL, females, $48 \mathrm{~mm}$ SL, male; BMNH 1933.10.31.6, caudal missing, syntype; RUSI 051901, 15 mm SL, sex unknown; SAM 17995, 70 mm SL, male, syntype; ZMUC P77470, 65 mm SL, male.

Bidenichthys consobrinus [3] 
AMS I.182812001, 67 mm SL, female, 65 mm SL, male; AMS I.182822007, 47, 62, 65 mm SL, males; NMNZ P.4118, 88 mm SL, female; NMNZ P.8001, 42, 66 mm SL, females; NMNZ P.8002, 32 mm SL, juvenile; NMNZ P.9542, 64 mm SL, female; NMNZ P.13607, 83 mm SL, male; NMNZ P.14103, 62 mm SL, male; NMNZ P.14391 (8 specimens), 19, 58, $63 \mathrm{~mm}$ SL, juveniles, 73, 85 mm SL, females, 54, 61, 63 mm SL; NMNZ P.14812, 59 mm SL, male; NMNZ P.15263, 54, 60, mm SL, males; NMNZ P.15317, 35 mm SL, juvenile; NMNZ P.15375, 39 mm SL, female; NMNZ P.15416, 62 mm SL, male; NMNZ P.15416; 40 mm SL, female; NMNZ P.15416, 38 mm SL, female; NMNZ P.17029, 78 mm SL, female; NMNZ P.17029, 70 mm SL, male; NMNZ P.17029, 60 mm SL, female; NMNZ P.17029, 73 mm SL, male; NMNZ P.17029, 74 mm SL, female; NMNZ P.17050, 75 mm SL, male; NMNZ P.17050, $81 \mathrm{~mm}$ SL, female; NMNZ P.17064, $70 \mathrm{~mm}$ SL, male; NMNZ P.17219, $77 \mathrm{~mm}$ SL, sex unknown; NMNZ P.17349, 21 mm SL, juvenile; NMNZ P.18273, 74 mm SL, male; NMNZ P.18300 (11 specimens), (paratypes of B. beebleboxi); NMNZ P.18415, 77 mm SL, male (holotype of B. beebleboxi); NMNZ P.18446; NMNZ P.18457, 68, 75 mm SL, females, 50, 60 mm SL, males; NMNZ P.21623, 33, 36, 72 mm SL, females, 62, 63, 65 mm SL, males; NMNZ P.21777, 34 mm SL, female; NMNZ P.21800, 60, 70 mm SL; NMNZ P.21853, 61, 87 mm SL, females, 58, 59 mm SL, males; NMNZ P.22752, 67, 79 mm SL, females; NMNZ P.22958, 87 mm SL, female; NMNZ P.23183, 47, $56 \mathrm{~mm}$ SL, females, $58 \mathrm{~mm}$ SL, male; NMNZ P.23201, 62 mm SL, female; NMNZ P.23422 (10 specimens), 46, 57, 61, 90 mm SL, females, 71, 71, 75, 79, 82, 83 mm SL, males; NMNZ P.24700 (3 specimens); NMNZ P.25666, 53 mm SL, female; NMNZ P.25666, 22 mm SL, juvenile; NMNZ P.25679 (3 specimens) (paratypes of B. beebleboxi); NMNZ P.28022, 32, 33, 36, 39 mm SL, female; NMNZ P.28106, 39, 57 mm SL, female, 57 mm SL, male; NMNZ P.28165, 70 mm SL, male; NMNZ P.28223, 68 mm SL, female; NMNZ P.28234, 82 mm SL, female, 73 mm SL, male; NMNZ P.28300 (6 specimens); NMNZ P.28343, 36 mm SL, juveniles; 47, 61, 81 mm SL, females; NMNZ P.28403, 51, 67 mm SL, females; NMNZ P.28488 (2 specimens); NMNZ P.29817, 33, 39, 56, females; NMNZ P.29847, 30 mm SL, juveniles; NMNZ P.29928, 70, 71 mm SL, males; NMNZ P.29973, 61 mm SL, male; NMNZ P.30000, 76 mm SL, female; NMNZ P.30025, 31, 32, 42, 45, 50, 52, $63 \mathrm{~mm} \mathrm{SL}, 46,52,59,64$, 66 females, 52, 52, 53, 47, 56, 57, $58 \mathrm{~mm} \mathrm{SL,}$ males; NMNZ P.30075, 61 mm SL, female; NMNZ P.30096, 67 mm SL, male; NMNZ P.30130, 34 mm SL, juvenile 72 mm SL, male; NMNZ P.30130; 47 mm SL female; NMNZ P.30978, $47 \mathrm{~mm}$, female $81 \mathrm{~mm}$ SL, male; NMNZ P.32888, $22 \mathrm{~mm}$ SL, juvenile, 60, 75, 76 mm SL, females, 62 mm SL, male; NMNZ P.33204, 35 mm SL, female; NMNZ P.33232, 80 mm SL; NMNZ P.33262, 40 mm SL, female; NMNZ P.35536, 49, 66, 79 mm SL, females; NMNZ P.35578, 45, $71 \mathrm{~mm}$ SL, females, 77 mm SL, male; NMNZ P.35594, 47, 48 mm SL, females, 80 mm SL, male; NMNZ P.36609, 50 mm SL, female, 64, 65 mm SL, males, NMNZ P.36646, 66 mm SL, male; NMNZ P.36730, 78, 79, 79 mm SL, females; NMNZ P.37429, 33 mm SL, juvenile; NMNZ P.3746 (1 specimen); NMNZ P.4118, 88 mm SL, female; NMNZ P.46271, 55 mm SL, female; SNMS 14134, 67 mm SL, female; ZMUC P77800-03, 84, 91 mm SL, females, 78, $83 \mathrm{~mm}$ SL, males.

Bidenichthys paxtoni [5]

AMS E.5264, 74 mm SL, female, holotype; NMNZ P.7830, 115 mm SL, female; NMNZ P.18430, 149 mm SL, female.

Bidenichthys slartibartfasti [6]

NMNZ P.32145, 127 mm SL, female; NMNZ P.35012, 32 mm SL, female; NMNZ P.35097, 109 mm SL, male; NMNZ P.35097, 93 mm SL, female; NMNZ P.032270, 57 mm SL, sex unknown; NMNZ P.30313, 102 mm SL, male, paratype; NMNZ P.30323, 93 mm SL, female, holotype. 


\section{References}

1. Barnard, K.H. New records and descriptions of two new species of South African marine fishes. Ann. Mag. Nat. Hist. 1934, 10, 228-234. [CrossRef]

2. Møller, P.R.; Knudsen, S.W.; Schwarzhans, W.; Nielsen, J.G. A new classification of viviparous brotulas (Bythitidae)—With family status for Dinematichthyidae-Based on molecular, morphological and fossil data. Mol. Phylogenetics Evol. 2016, 100, 391-408. [CrossRef] [PubMed]

3. Hutton, F.W. Contributions to the ichthyology of New Zealand. Trans. N. Z. Inst. 1876, 8, $209-218$.

4. Hector, J. Notes on New Zealand ichthyology. Trans. N. Z. Inst. 1877, 9, 465-469.

5. Nielsen, J.G.; Cohen, D.M. Melodichthys, a new genus with two new species of upper bathyal bythitids (Pisces, Ophidiiform). Cybium 1986, 10, 381-387.

6. Paulin, C.D. Description of a new genus and two new species of bythitid fishes, and a redescription of Bidenichthys consobrinus (Hutton) from New Zealand. J. Nat. Hist. 1995, 29, 249-258. [CrossRef]

7. Møller, P.R.; Nielsen, J.G. 98 Family Bythitidae. In The Fishes of New Zealand; Roberts, C.D., Stewart, A.L., Struthers, C.D., Eds.; Te Papa Press: Wellington, New Zealand, 2015; pp. 720-735.

8. Nielsen, J.G.; Cohen, D.M.; Markle, D.F.; Robins, C.R. An Annotated and Illustrated Catalogue of Pearlfishes, Cusk-Eels, Brotulas and Other Ophidiiform Fishes Known to Date; FAO Species Catalogue. Ophidiiform Fishes of the World (Order Ophidiiformes). In FAO Fisheries Synopsis; FAO: Rome, Italy, 1999; p. 178.

9. Møller, P.R.; Schwarzhans, W.; Nielsen, J.G. Review of the American Dinematichthyini (Teleostei, Bythitidae). Part I. Dinematichthys, Gunterichthys, Typhliasina and two new genera. Aqua J. Icht. Aquat. Biol. 2004, 8, 141-192.

10. Sabaj, M.H. Standard Symbolic Codes for Institutional Resource Collections in Herpetology and Ichthyology; Version 7.1; American Society of Ichthyologists and Herpetologists: Washington, DC, USA, 2019. Available online: http:/ / www.asih.org (accessed on 21 March 2019).

11. Clouard, V.; Bonneville, A. Ages of seamounts, islands, and plateaus on the Pacific plate. In Plates, Plumes and Paradigms; Foulger, G.R., Natland, J.H., Presnall, D.C., Anderson, D.L., Eds.; Geological Society of America: Boulder, CO, USA, 2005; pp. 71-90.

12. Clague, D.A.; Braga, J.C.; Bassi, D.; Fullagar, P.D.; Renema, W.; Webster, J.M. The maximum age of hawaiian terrestrial lineages: Geological constraints from Koko Seamount. J. Biogeogr. 2010, 37, 1022-1033. [CrossRef]

13. Sharp, W.D.; Clague, D.A. 50-Ma initiation of Hawaiian-Emperor bend records major change in Pacific plate motion. Science 2006, 313, 1281-1284. [CrossRef]

14. Clague, D.A.; Dalrymple, G.B.; Greene, H.G.; Wald, D.; Kono, M.; Kroenke, L.W. Bathymtery of the Emperor Seamounts. Init. Rep . Deep Sea Drill. Pro. 1980, 55, 845-849.

15. Schwarzhans, W. Reconstruction of the fossil marine bony fish fauna (Teleostei) from the Eocene to Pleistocene of New Zealand by means of otoliths. Memorie della Società Italiana di Scienze Naturali e del Museo di Storia Naturale di Milano 2019, 46, 3-326.

16. Howes, G.J. Notes on the anatomy and classification of ophidiiform fishes with particular reference to the abyssal genus Acanthonus Günther, 1878. Bull. Br. Mus. Nat. Hist. (Zool.) 1992, 58, 95-131.

17. Carnevale, G.; Johnson, D. A Cretaceous Cusk-Eel (Teleostei, Ophidiiformes) from Italy and the Mesozoic Diversification of Percomorph Fishes. Copeia 2015, 103, 771-791. [CrossRef]

18. Nolf, D. Etude monographique des otolithes des Ophidiiformes actuels et révision des espèces fossiles (Pisces, Teleostei). Mededelingen van de Werkgroep voor Tertiaire en Kwartaire Geologie 1980, 17, 71-195.

19. Schwarzhans, W. Vergleichende morphologische Untersuchungen an rezenten und fossilen Otolithen der Ordnung Ophidiiformes. Berliner Geowissenschaftliche Abhandlungen (A) 1981, 32, 63-122.

20. Nielsen, J.G.; Schwarzhans, W.; Cohen, D. 2012 Revision of Hastatobythites and Saccogaster (Teleostei, Bythitidae) with three new species and a new genus. Zootaxa 2012, 3579, 1-36. [CrossRef]

21. Gaemers, P.A.M. Fish otoliths from the Bassevelde Sand (Late Tongrian) of Ruisbroek, Belgium, and the stratigraphy of the Early Oligocene of Belgium. Meded. Werkgr. Tert. Kwart. Geol. 1984, 21, 13-57.

22. Voigt, E. Über ein bemerkenswertes Vorkommen neuer Fischotolithen in einem Senongeschiebe von C€othen in Anhalt. Z. Geschiebeforschung 1926, 2, 172-187.

23. Nolf, D. Les otolithes des téléostéens des Formations de Landen et de Heers (Paléocène de la Belgique). Geol. Palaeontol. 1978, 12, 223-234.

24. Schwarzhans, W. Fish Otoliths from the New Zealand Tertiary; New Zealand Geological Survey: Wellington, New Zealand, 1984. [CrossRef]

25. Nolf, D.; Dockery, D.T. Fish otoliths from the Matthews Landing Marl Member (Porters Creek Formation), Paleocene of Alabama. Miss. Geol. 1993, 14, 24-39.

26. Lanckneus, J.; Nolf, D. Les otolithes des téléostéens redoniens de Bretagne (Néogène de l'Ouest de la France). Bulletin de l'Institut de Géologie du Bassin d'Aquitaine. Bulletin de l'Institut de Géologie du Bassin d'Aquitaine 1979, 25, 83-109.

27. Eschmeyer, W.N.; Abe, T.; Nakano, S. Adelosebastes latens, a new genus and species of scorpionfish from the North Pacific Ocean (Pisces, Scorpaenidae). Jpn. Soc. Ichthyol. 1979, 30, 77-84.

28. Iwamoto, T.; Okamoto, M. A new grenadier fish of the genus Lucigadus (Macrouridae, Gadiformes, Teleostei) from the Emperor Seamounts, Northwestern Pacific. Proc. Calif. Acad. Sci. 2015, 62, 369-380.

29. Wilson, R.R.; Kaufmann, R.S. Seamount biota and biogeography. Geophys. Monogr. Ser. 1987, 43, 355-377. 
30. Stocks, K.I.; Hart, P.J.B. Biogeography and biodiversity of seamounts. In Seamounts: Ecology, Fisheries and Conservation; Pitcher, T.J., Morato, T., Hart, P.J.B., Clark, M.R., Haggan, N., Santos, R.S., Eds.; Fish and Aquatic Resources Series; Blackwell: Oxford, UK, 2007; pp. 255-281.

31. Shank, T.M. Seamounts: Deep-ocean laboratories of faunal connectivity, evolution, and endemism. Oceanography 2010, 23, 109-122. [CrossRef]

32. Hart, P.J.B.; Pearson, E. An application of the theory of island biogeography to fish speciation on seamounts. Mar. Ecol. Prog. Ser. 2011, 430, 281-288. [CrossRef] 